SAS were correlated with the PtGA of disease activity as $83 \%$ for the derivation cohort and $75 \%$ for the validation cohort, also, correlation of this score and patient's global VAS assessments were $79 \%$ and $73 \%$, respectively. Sensitivity and specificity of SAS equal and/or higher than 4 to predict " active (severe) and highly active (more severe) AOSD activity" are $100 \%$ and $82.6 \%$, respectively (Figure 1).

Conclusion: In this study, we created a Still activity score (SAS) with the routine clinical and laboratory features of patients. This score can detect patients who have high likelihood of being in active disease status. In the future perspective, SAS should be assessed in the clinical trials and routine practice.

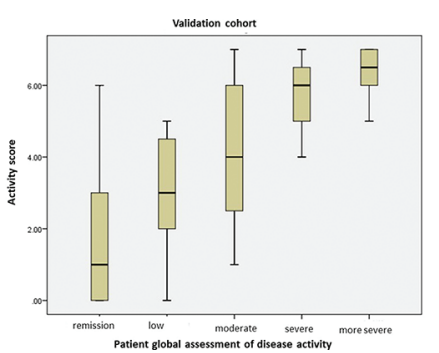

Figure 1. Boxplot of SAS and patients' global assessment of disease activity

Table 1. Still activity score (SAS)

\begin{tabular}{lccc}
\hline & 0 point & $\begin{array}{c}\mathbf{1} \\
\text { point }\end{array}$ & 2 points \\
\hline $\begin{array}{l}\text { Fever } \\
\text { Arthralgia }\end{array}$ & Absent & & $\begin{array}{c}\text { Present } \\
\text { Present } \\
\text { * }\end{array}$ \\
Neutrophilia\% $\geq 65$ & Absent & & \\
Ferritin $\geq 350 \mathrm{ng} /$ & No & Yes & \\
\hline m & No & Yes &
\end{tabular}

*If number of swollen joints $\geq 2$, add 1 point.

Disclosure of Interests: Umut Kalyoncu Grant/research support from: MSD, Roche, UCB, Novartis and Pfizer, Consultant for: MSD, Abbvie, Roche, UCB, Novartis, Pfizer and Abdi Ibrahim, Speakers bureau: MSD, Abbvie, Roche, UCB, Novartis, Pfizer and Abdi Ibrahim, Timuçin Kaşifoğlu: None declared, Ahmet Omma: None declared, Cemal Bes: None declared, Muhammet Çınar: None declared, Hakan Emmungil Grant/research support from: MSD, Roche, Pfizer, Abbvie, Consultant for: Novartis, Roche, Speakers bureau: MSD, Roche, Pfizer, Abbvie,Celltrion, Novartis, Orhan Küçükşahin: None declared, Servet Akar Grant/ research support from: MSD, Abbvie, Roche, UCB, Novartis, Pfizer, Amgen, Consultant for: MSD, Abbvie, Roche, UCB, Novartis, Pfizer, Amgen, Speakers bureau: Pfizer, Kenan Aksu: None declared, Fatih Yıldız: None declared, Nilüfer Alpay Kanıtez: None declared, Abdulsamet Erden: None declared, Emre Bilgin: None declared, Sezin Turan: None declared, Ediz Dalkılıç Grant/research support from: MSD and Abbvie, Consultant for: MSD, Abbvie,Roche, UCB, Pfizer and Novartis, Speakers bureau: MSD, Abbvie,Roche, UCB, Pfizer and Novartis, Selime Ermurat: None declared, Kadir Mutlu Hayran: None declared DOI: 10.1136/annrheumdis-2019-eular.3391

\section{OP0169 \\ LONG-TERM SURVIVAL IN LUNG TRANSPLANTATION FOR INTERSTITIAL LUNG DISEASE ASSOCIATED WITH CONECTIVE TISSUE DISEASES. STUDY OF 26 CASES OF A SINGLE CENTER}

D. Prieto-Peña, Monica Calderón-Goercke, Amaya Martínez-Meñaca, Victor Manuel Mora-Cuesta, Sonia Fernández-Rozas, David Iturbe-Fernández, Jose Manuel Cifrián-Martínez, Miguel A González-Gay, Ricardo Blanco. Marqués de Valdecilla University Hospital, Santander, Spain

Background: Interstitial lung disease (ILD) is one of the most serious complications associated with connective tissue diseases (CTD). Patients with ILD have increased mortality and limited treatment options. Lung transplant has been recognized as an option for patients with end-stage CTD-ILD. However, rheumatic diseases are still sometimes considered a contraindication for lung transplant because of concerns for worse outcomes.
Objectives: Our aims were to: a) assess long-term post-transplant survival in patients with CTD-ILD and $\mathbf{b}$ ) compare post post-transplant survival of patients with CTD-ILD with patients with idiopathic pulmonary fibrosis (IPF).

Methods: Single center study in a referral center for lung transplant of all patients who underwent lung transplantation for CTD-ILD between 1998 and 2017. This cohort was compared with patients with IPF (group-matched for age, transplant year and basiliximab induction). Cumulative survival rates after transplantation were estimated by the Kaplan-Meier method and compared between groups using the log-rank test.

Results: We studied 26 patients with CTD-ILD matched to 26 patients with IPF. The underlying diseases of patients with CTD-ILD were: Rheumatoid arthritis $(n=9)$, Scleroderma $(n=6)$, Sjögren syndrome $(n=4)$, ANCA-vasculitis $(n=3)$, Ant synthetase syndrome $(n=2)$, Dermatomyositis $(n=1)$, Systemic lupus erythematosus $(n=1)$. The comparative study of baseline characteristics between both groups is shown in the TABLE. All of RA patients undergoing transplantation in our study had the histologic subtype of usual interstitial pneumonia (UIP) whereas non-specific interstitial pneumonia (NSIP) was the most common histologic subtype of ILD associated with the rest of CTD. Cumulative survival rates at 5 year post-transplant did no differ significantly between CTD-ILD and IFP $[42.4 \%$ vs $65.8 \%$ $(p=0.075)$ ] (FIGURE 1)

\begin{tabular}{|c|c|c|c|}
\hline \multicolumn{4}{|c|}{ † TABLE } \\
\hline & IPF (n=26) & CTD-ILD ( $n=26)$ & $\mathbf{P}$ \\
\hline Age (years), mean $\pm S D$ & $60.4 \pm 5.3$ & $56.5 \pm 8.3$ & 0.06 \\
\hline Sex (women), $n(\%)$ & $6(23.1)$ & $18(69.2)$ & 0.001 \\
\hline $\begin{array}{l}\text { Time on waiting list (days), } \\
\text { median [IQR] }\end{array}$ & \begin{tabular}{|l|}
$86.0[35.5-$ \\
$268.3]$ \\
\end{tabular} & $\begin{array}{l}82.0[37.0- \\
212.3] \\
\end{array}$ & 0.78 \\
\hline Smokers, $\mathrm{n}(\%)$ & $19(73.1)$ & $11(42.3)$ & 0.07 \\
\hline $\begin{array}{l}\text { Type of transplant } \\
\text { (bilateral), } \mathrm{n}(\%)\end{array}$ & $8(30.8)$ & $13(50.0)$ & 0.16 \\
\hline $\begin{array}{l}\text { Donor CMV + and recipient } \\
\text { CMV -, } \mathrm{n}(\%)\end{array}$ & $4(15.3)$ & $2(7.7)$ & 0.72 \\
\hline Basiliximab induction, $n(\%)$ & $9(34.6)$ & $9(34.6)$ & 0.99 \\
\hline \multicolumn{4}{|c|}{\begin{tabular}{|l|l} 
Variables at transplant & \\
\end{tabular}} \\
\hline FEV $1(\%)$, median [IQR] & 57 [35.5-71.3] & $50[41.0-60.0]$ & 0.34 \\
\hline FVC (\%), median [IQR] & $54[36.0-65.8]$ & $51[44.0-61.0]$ & 0.55 \\
\hline FEV1/FVC, median [IQR] & $82[75.9-88.5]$ & $80[72.0-89.1]$ & 0.52 \\
\hline DLCO & $24[18.7-42.0]$ & $30[23.0-43.5]$ & 0.49 \\
\hline KCO & $66[49.5-82.5]$ & $68[42.9-78.0]$ & 0.54 \\
\hline $\begin{array}{l}\text { Serum creatinine }(m g / d L) \\
\text { mean } \pm \mathrm{SD}\end{array}$ & $0.78 \pm 0.14$ & $0.80 \pm 0.31$ & 0.74 \\
\hline Right catheterization, $\mathbf{n}(\%)$ & $11(42.3)$ & $16(61.5)$ & 0.07 \\
\hline mPAP $(m m H g)$, mean $\pm S D$ & $23.3 \pm 3.8$ & $26.5 \pm 8.6$ & 0.15 \\
\hline $\mathrm{PCP}(m m \mathrm{Hg})$, mean $\pm \mathrm{SD}$ & $13.3 \pm 2.7$ & $12.0 \pm 4.7$ & 0.44 \\
\hline \multicolumn{4}{|l|}{ Treatment pre-transplant } \\
\hline Glucocorticoids, $n$ (\%) & $20(76.9)$ & $23(88.5)$ & 0.22 \\
\hline $\begin{array}{l}\text { Immunosuppressive drugs, } \\
\text { n (\%) }\end{array}$ & $7(26.9)$ & $21(80.8)$ & 0.001 \\
\hline \multicolumn{4}{|l|}{ Allograft dysfunction } \\
\hline Acute rejection & $15(62.5)$ & $8(32.0)$ & 0.032 \\
\hline Chronic rejection & $2(8.3)$ & $5(20.0)$ & 0.417 \\
\hline
\end{tabular}

CTD-ILD: interstitial Iung disease related with connective tissue diseases; DLCO: diffusing capacity of lung for carbon monoxide; IFP: idiopathic pulmonary fibrosis; KCO: transfer coefficient of the lung for carbon monoxide; RA-ILD: monoxide; IFP: idiopathic pulmonary fibrosis; KCO: transfer coefficient of the lung for carbon monoxide; RA-ILD:
interstitial lung disease related with rheumatoid arthritis; mPAP: mean pulmonary arterial pressure; PCP: pulmonary capillary pressure.

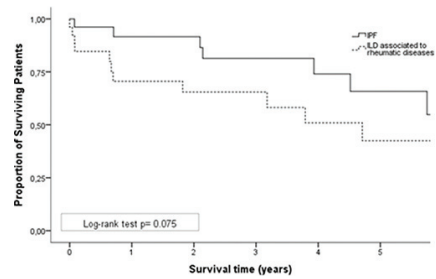

Conclusion: Our retrospective analysis showed a trend to lower long-term posttransplant survival than in those with IPF, however no statistical differences were found in cumulative survival rates at 5 -years post-transplant. These data support that lung transplantation should be considered in patients with end-stage CTD ILD.

Disclosure of Interests: D. Prieto-Peña: None declared, Monica CalderónGoercke: None declared, Amaya Martínez-Meñaca: None declared, Victor Manuel Mora-Cuesta: None declared, Sonia Fernández-Rozas: None declared, David Iturbe-Fernández: None declared, Jose Manuel Cifrián-Martínez: None declared Miguel A González-Gay Grant/research support from: Prof. MA Gonzalez-Gay received grants/research supports from Abbvie, MSD, Jansen and Roche. Speakers bureau: Consultation fees/participation in company sponsored speaker's bureau from Pfizer, Lilly, Sobi, Celgene, Novartis, Roche and Sanofi. Ricardo Blanco Grant/research support from: Abbvie, MSD, and Roche, Consultant for: Abbvie, Pfizer, Roche, Bristol-Myers, Janssen, Speakers bureau: Abbvie, Pfizer, Roche, Bristol-Myers, Janssen 
DOI: 10.1136/annrheumdis-2019-eular.3564

\section{OP0170 USE OF THE PROVISIONAL EULAR/ACR IGG4-RD CLASSIFICATION CRITERIA IN A COHORT OF SPANISH PATIENTS}

Andreu Fernandez-Codina ${ }^{1}$, Blanca Pinilla ${ }^{2}$, lago Pinal-Fernandez ${ }^{3}$, Carlos FeijooMasso $^{4}$, Miguel Lopez-Dupla ${ }^{5}$, Eva Fonseca ${ }^{6}$, Olimpia Orozco-Galvez ${ }^{7}$, Fernando Martínez-Valle ${ }^{8}$, Registro Español de Enfermedad Relacionada con la IgG4 (REERIGG4) GEAS/SEMI. ${ }^{1}$ Western University, Rheumatology and Internal Medicine, London, Canada; ${ }^{2}$ Hospital Gregorio Maranon, Internal Medicine, Madrid, Spain; ${ }^{3}$ National Institute of Arthritis and Musculoskeletal and Skin Diseases, Muscle Disease Unit, Bethesda, United States of America; ${ }^{4}$ Consorci Sanitari Parc Tauli, Internal Medicine, Sabadell, Spain; ${ }^{5}$ Hospital Joan XXIII, Internal Medicine, Tarragona, Spain; ${ }^{6}$ Hospital de Cabuenes, Gijon, Spain; ${ }^{7}$ Hospital Universitari Vall d'Hebron, Internal Medicine, Barcelona, Spain; ${ }^{7}$ Hospital Universitari Vall d'Hebron, Internal Medicine, Barcelona, Spain

Background: The ACR/EULAR IgG4-related disease (IgG4-RD) provisional classification criteria were presented at the ACR conference in 2018. The performance of these criteria in a fully non-Asian cohort is unknown.

Objectives: To explore the performance of these provisional criteria in a cohort of Spanish patients with IgG4-RD.

Methods: Data were obtained from the Spanish IgG4-RD registry (REERIgG4) from October 2013 to December 2018, including 9 centers. Patients needed to fulfill almost 1 of the available diagnostic criteria sets (pathology consensus and/or comprehensive). $\mathrm{N}$ provisional ACR/EULAR classification criteria (PAECC) were applied based on the public information disclosed at the abovementioned meeting.

Results: One-hundred patients were included. Thirty-four (34\%) were females, median age at diagnosis was 54.8 years (IQR 20.7). The ethnicity of the participants was: Caucasian $83 \%$, Hispanic $12 \%$ and North-African/MiddleEast $5 \%$. Ninety-two percent were diagnosed with a biopsy. Regarding the diagnostic criteria, $85 \%$ met consensus pathology criteria and $94 \%$ comprehensive criteria.

Fifty-one patients $(51 \%)$ had systemic lgG4-RD involving $>1$ tissue. The most commonly involved tissues were: retroperitoneum (35\%), lymph nodes (19\%), orbit pseudotumor (18\%), salivary glands (16\%) and pancreas (14\%). Forty-two patients (42\%) had elevated serum IgG4.

Seventy-one individuals $(71 \%)$ met the PAECC including entry criteria, exclusion criteria with an inclusion criteria score equal or $>19$ points. From the 29 cases that did not meet the PAECC, $9(31 \%)$ did not fulfill the first step (entry). Those patients had rarer organs involved as hypophysis, mesenterium or jaw. Eight patients $(28 \%)$ met one of the exclusion items. Two had positive antineutrophil cytoplasmic antibodies, 2 steroid resistance, 2 double-stranded antideoxyribonucleic acid antibodies, 1 other specific autoantibodies, 1 eosinophilia and fever. None of them had evidence of active connective tissue disease, vasculitis, malignancy or infection. Finally, 16 of the patients who did not meet the PAECC (55\%) had an inclusion criteria score under 19 points (median 12): 3 $(19 \%)$ did not have a biopsy, $8(50 \%)$ biopsies had partial reports, and 10 subjects $(62.5 \%)$ had normal serum IgG4 levels. Six (38\%) of them had involvement limited to the head and neck and $3(19 \%)$ had retroperitoneal or aortic involvement.

Conclusion: Seventy-one percent of the Spanish patients participating in the REERIgG4 met the 2018 PAECC, while all of them met almost one of the previous diagnostic criteria. Populations with non-Asian ancestry might get lower scores, as they would make less points in significant domains (serum IgG4, pancreatic-biliary) or have presentations that may grant lower scores or exclusion. Enforcing complete pathology reports might increase the scores. Nevertheless, the new classification criteria are provisional and primarily intended for clinical trial recruitment, focusing in the most common manifestations. Therefore, the preexisting diagnostic criteria should be used for standard clinical purposes.

\section{REFERENCE:}

[1] Wallace Zs, Naden RP, Choi H. The 2018 ACR/EULAR Classification Criteria for igG4- Related Disease. Submitted 2018.

Disclosure of Interests: None declared

DOI: 10.1136/annrheumdis-2019-eular.3751
THURSDAY, 13 JUNE 2019

\section{From child to adult care - breaking down the barriers of transition}

\section{OP0171-PARE THE SWEDISH YOUNG RHEUMATICS REPORT - THE MOST URGENT MATTERS AND THE MOST PROMISING DEVELOPMENT AREAS FOR YOUNG PEOPLE WITH RMD'S IN SWEDEN}

Cajsa Helin Hollstrand, Kim Nordlund, Madeleine Beermann. The Swedish

National Organization for Young Rheumatics, Stockholm, Sweden

Background: In May 2017, the Swedish National Organization for Young Rheumatics (Unga Reumatiker) adopted its first political program. The program is composed by six areas and within every section we have stated what our organization want and what changes we see as necessary. To make sure we are working with the most urgent matters for our members and all of the young people with RMD's in Sweden, we wanted to do a survey, based on our political wills, amongst our members. The survey was conducted in the Autumn of 2017, with support by Pfizer, and the results were presented in the Swedish Young Rheumatics Report (Unga Reumatiker-rapporten) in April 2018.

Objectives: By conducting a survey and presenting a report, we wanted to highlight what are the largest obstacles for young people with RMD's in Sweden today. What areas need change, and what great solutions already exists? Answering these questions has been of great help for us as an organization, because we now know what matters the most to our members and what we need to focus on, but it is also of great help to others. It is for example much easier for healthcare professionals to work on fixing existing issues, now that they know what issues are of most concern for their patients. We also wanted to raise awareness about the situation for young people with RMD's in Sweden today, and inspire these people to follow their dreams.

Methods: The survey was conducted digitally and was sent out to our $1550 \mathrm{mem}$ bers and 425 people answered the survey, which consisted of 40 questions. After analyzing what stood out the most and seemed most urgent and important to the respondents, the report was composed with the most remarkable survey results, divided into four headlines; education and support, from child to adult, healthcare and treatment, and sex and family planning. We created www.ungareumatikerrapporten.se where the results are presented, and also personalized by four members telling their stories and sharing their dreams. As another part of the report, we also developed a new tool called the Dream Scale (Drömskalan). It is our response to the standard pain scale, VAS, and it is a tool meant to help inspire our members to dare to follow their dreams.

Results: We launched the report the $10^{\text {th }}$ of April with the campaign hashtag \#wearenotourdisease (\#viärintevårsjukdom). We wanted to make sure to focus on joy of life and dreams to inspire our members, while at the same time highlight some problematic areas that needs to be adjusted. With the hashtag, we also wanted to create a sense of community, and invite people to share their own stories and dreams. We published the results and shared the videos from the report website on our social media for two weeks, including popular takeovers, and got a lot of attention. We published a debate article in Dagens Medicin, Sweden's leading health care newspaper, about how it is time for a focus shift within the healthcare system. And we have sent out printed copies of the report to all clinics in Sweden, and have also lectured and keep on lecturing about the report and our work at clinics all over Sweden.

Conclusion: There is still a lot to do and a lot of changes still have to be made if all young rheumatics shall be able to experience joy of life and fulfill their dreams but the report helped us take a giant step in the right direction. We have raised awareness about what problems young people with RMD's in Sweden face on a daily basis. We know what the most urgent matters are and also what solutions we need to push for when working and talking with politicians and other decision makers. And we have been able to shift the conversation and the focus from just talking about what's bad, to talking about joy of life, hopes and dreams. We have empowered our members and others, telling them to share their own stories and dare to pursue their dreams. Having a rheumatic disease should never prevent you from living your life to the fullest!

REFERENCE:

[1] www.ungareumatikerrapporten.se

Disclosure of Interests: None declared DOI: 10.1136/annrheumdis-2019-eular.7117 